\title{
Pengembangan perangkat pembelajaran ekosistem berbasis inkuiri dengan sumber belajar danau betok untuk mengembangkan keterampilan dan sikap ilmiah siswa kelas VII SMPN 1 Tiris Probolinggo
}

\author{
Endang Rahmi Nur Laili, Ibrohim*, Novida Pratiwi \\ Universitas Negeri Malang, Jl. Semarang No. 5 Malang, Jawa Timur, Indonesia \\ *Penulis korespondensi, Surel: ibrohim.fmipa@um.ac.id
}

Paper received: 01-02-2021; revised: 15-02-2021; accepted: 28-02-2021

\begin{abstract}
The objective of this research was to produce a learning instrument based on inquiry in ecosystem with Betok Lake as learning resource were valid and viable to used. The model of development on this research was using Borg and Gall's model. The result of this research is the learning instrument consist of syllabus, design learning, assessment instrument, students' worksheet, and handout showed was valid with the validity 96.2 percent. The test result showing that the scientific attitude were 83.33 percent with good criterion, scientific skill were 81.79 percent with good criterion, and knowledge students were 79.30 are fill the KKM. The implementation assessment showed 93.7 percent value which is means that learning instrument was applied so well.
\end{abstract}

Keywords: learning instrument; inquiry; Betok Lake; scientific skills; scientific attitude

\begin{abstract}
Abstrak
Tujuan penelitian ini untuk menghasilkan produk perangkat pembelajaran berbasis potensi wilayah yang valid dan layak digunakan. Penelitian ini menggunakan model pengembangan Borg \& Gall (1983). Hasil dari penelitian ini adalah perangkat pembelajaran yang berupa silabus, RPP, instrumen penilaian dan bahan ajar (LKS dan handout) yang valid dengan nilai validitas 96,2 persen. Hasil uji coba perangkat pembelajaran menunjukkan bahwa nilai rata-rata sikap ilmiah sebesar 83,33 persen dengan kriteria baik, keterampilan ilmiah sebesar 81,79 persen dengan kriteria baik, dan rata-rata nilai pengetahuan sebesar 79,30 sehingga memenuhi KKM (Kriteria Ketuntasan Minimal). Hasil penilaian keterlaksanaan pembelajaran menunjukkan nilai 93,7 persen yang artinya perangkat pembelajaran terpakai dengan baik.
\end{abstract}

Kata kunci: perangkat pembelajaran; inkuiri; Danau Betok; keterampilan ilmiah; sikap ilmiah

\section{Pendahuluan}

Berisi latar belakang, rasional, state of the art untuk menunjukkan kebaruan ilmiah artikel yg ditulis dan atau urgensi penelitian serta tujuan penelitian. Referensi (pustaka atau penelitian relevan), perlu dicantumkan dalam bagian ini, hubungannya dengan justifikasi urgensi penelitian, pemunculan permasalahan penelitian, alternatif solusi, dan solusi yang dipilih. Cara penulisan sumber dalam teks menggunakan style APA edisi keenam. Sebagai contoh adalah: hasil penelitian menunjukkan bahwa lebih dari $70 \%$ siswa tidak mampu mengenali permasalahan otentik (Retnawati, 2014). Penulis disarankan menggunakan aplikasi manajer referensi seperti mendeley, zotero, atau endnote.

Derajat kemutakhiran bahan yang diacu dengan melihat proporsi 10 tahun terakhir dan mengacu pustaka primer. Permasalahan dan tujuan, serta kegunaan penelitian ditulis secara naratif dalam paragraf-paragraf, tidak perlu diberi subjudul khusus. Demikian pula definisi operasional, apabila dirasa perlu, juga ditulis naratif. 


\section{Metode}

Penelitian ini adalah penelitian Research and Development (R\&D) atau penelitian pengembangan yang menggunakan model pengembangan Borg dan Gall (1983). Model penelitian Borg dan Gall (1983) yang diterapkan yaitu: (1) penelitian dan pengumpulan data, (2) perencanaan, (3) pengembangan bentuk produk pendahuluan, (4) uji coba pendahuluan, (5) revisi terhadap produk utama, (6) uji coba utama yang didasarkan pada hasil uji coba pendahuluan, dan (7) revisi produk operasional. Data yang diperoleh berupa data kuantitatif dan kualitatif.

Instrumen yang digunakan untuk mengumpulkan data pada penelitian ini berupa lebar validasi untuk validator dan praktisi lapangan. Lembar validasi ini berisi skala likert dengan rentang skor 1-4. Kriteria kevalidan perangkat pembelajaran berdasarkan perolehan penilaian angket, disimpulkan menurut Tabel 1 berikut.

Tabel 1 Deskripsi Penilaian Menggunakan Skala Likert

\begin{tabular}{|c|c|}
\hline & Keterangan \\
\hline $81 \%-100 \%$ & Sangat valid \\
\hline $61 \%-80 \%$ & Valid \\
\hline $41 \%-60 \%$ & Cukup valid \\
\hline $21 \%-40 \%$ & Kurang valid \\
\hline $0 \%-20 \%$ & Tidak valid \\
\hline
\end{tabular}

(Sumber: Riduwan, 2004)

\section{Hasil dan Pembahasan}

\section{Hasil Validasi Perangkat Pembelajaran Ekosistem}

Perangkat pembelajaran yang dikembangkan memiliki komponen berupa silabus, RPP, instrumen penilaian, dan bahan ajar. Silabus yang dikembangkan mengacu pada lampiran Peraturan Mentri Pendidikan dan Kebudayaan No. 65 Tahun 2013 Tentang Standar Proses Pendidikan Dasar dan Menengah. Silabus merupakan acuan penyusunan kerangka pembelajaran untuk setiap pengembangan RPP. Silabus yang dikembangkan terdiri atas beberapa komponen, yaitu: 1) identitas mata pelajaran, 2) identitas sekolah berupa satuan pendidikan dan kelas, 3) kompetensi inti, 4) kompetensi dasar, 5) indikator, 6) materi pokok, 7) kegiatan pembelajaran, 8) penilaian, 9) alokasi waktu, dan 10) sumber belajar.

RPP dikembangkan dari silabus untuk mengarahkan kegiatan pembelajaran yang dilakukan siswa dalam upaya mencapai Kompetensi Dasar (KD). RPP yang dikembangkan meliputi 1) identitas sekolah, 2) identitas mata pelajaran, 3) kelas/semester, 4) materi pokok, 5) alokasi waktu, 6) kompetensi inti, 7) kompetensi dasar dan indikator, 8) tujuan pembelajaran, 9) materi pembelajaran, 10) metode pembelajaran, 11) media pembelajaran, 12) sumber belajar, 13) langkah pembelajaran, dan 14) penilaian. RPP yang dikembangkan menggunakan metode pembelajaran inkuiri terbimbing dengan sumber belajar Danau Betok. RPP disusun terdiri dari 3 (tiga) pertemuan. Pertemuan pertama secara garis besar berisi kegiatan perencanaan pengamatan. Pertemuan kedua berisi kegiatan pengamatan ekosistem di Danau Betok. Pertemuan ketiga berisi kegiatan mengkomunikasikan dan evaluasi pembelajaran. 
Instrumen penilaian yang dikembangkan meliputi instrumen penilaian untuk mengukur sikap ilmiah, keterampilan ilmiah, dan pengetahuan siswa. Penilaian sikap dan keterampilan ilmiah dilakukan melalui observasi pada saat pembelajaran. Instrumen penilaian sikap dan keterampilan imiah dilengkapi dengan rubrik. Penilaian aspek pengetahuan melalui tes tulis individu dan penilaian LKS secara berkelompok.

Bahan ajar yang dikembangkan terdiri dari Lembar Kerja Siswa (LKS) dan handout. Lembar Kerja Siswa (LKS) dikembangkan dengan model inkuiri terbimbing. LKS yang dikembangkan terdiri dari: 1) identitas LKS, 2) judul kegiatan, 3) tujuan kegiatan, 4) alat dan bahan, 5) prosedur kerja, 6) tabel data, 7) analisis data (pertanyaan bimbingan dan diskusi), dan 8) kesimpulan. LKS dilengkapi dengan gambar-gambar untuk memberikan gambaran umum tentang sumber belajar Danau Betok kepada siswa. Handout yang dikembangkan berisi informasi yang berkaitan dengan materi ekosistem. Handout yang dikembangkan dilengkapi dengan peta konsep, kompetensi dasar dan indikator, kegaiatan pengamatan ekosistem, gambargambar yang diambil dari Danau Betok, fenomena IPA, dan tokoh IPA. Gambar yang tidak didapatkan dari hasil dokumentasi di Danau Betok dilengkapi dari internet yang mendukung.

Berdasarkan data validitas perangkat pembelajaran oleh validator, didapatkan hasil rata-rata persentase sebesar $96,2 \%$ yang menunjukkan perangkat pembelajaran yang dikembangkan sangat valid sehingga dapat digunakan dalam pembelajaran. Ringkasan validitas komponen perangkat pembelajaran selanjutnya tertera pada Tabel 2.

Tabel 2 Validitas Perangkat Pembelajaran

\begin{tabular}{lll}
\hline Komponen Perangkat Pembelajaran & Validitas Rata-rata (\%) & Kriteria \\
\hline Silabus & 97,5 & Sangat valid \\
RPP & 98,5 & Sangat valid \\
Istrumen penilaian sikap & 94,4 & Sangat valid \\
Istrumen penilaian keterampilan & 98,2 & Sangat valid \\
Istrumen penilaian pengetahuan & 94,6 & Sangat valid \\
LKS & 95,2 & Sangat valid \\
Handout & 95,0 & Sangat valid \\
\hline Rata-rata & 96,2 & Sangat valid \\
\hline
\end{tabular}

Data kualitatif berupa catatan komentar dan saran validator digunakan untuk melakukan revisi perangkat pembelajaran yang dikembangkan. Komentar/saran dari kedua validator terhadap perangkat pembelajaran adalah mengenai instrumen penilaian kurang menggunakan bahasa yang komunikatif. Bahan ajar yang dikembangkan (lembar kerja siswa dan handout) layout dan tampilannya perlu diperbaiki.

Nilai validitas silabus yang tinggi didapatkan karena silabus yang dikembangkan sesuai dengan Peraturan Mentri Pendidikan dan Kebudayaan No. 65 Tahun 2013 Tentang Standar Proses. Validitas silabus yang tinggi ini juga didapatkan dari kesesuain kompetensi dan kegiatan pembelajaran dengan kompetensi dan indikator pencapaian hasil belajar yang sesuai dengan jenjang pendidikannya. Kegiatan pembelajaran yang disusun telah menggambarkan pembelajaran yang berpusat pada 
siswa yang berbasis inkuiri. Pembelajaran inkuiri merupakan kegiatan pembelajaran yang melibatkan secara maksimal seluruh kemampuan siswa untuk mencari dan menyelidiki sesuatu (benda, lingkungan, manusia atau peristiwa) secara sistematis, kritis, logis, analitis sehingga siswa dapat merumuskan sendiri penemuannya (Mulyono, 2011).

Nilai validitas RPP yang tinggi didapatkan karena RPP yang dikembangkan sesuai dengan Peraturan Mentri Pendidikan dan Kebudayaan No. 65 Tahun 2013 Tentang Standar Proses. RPP yang disusun telah menggambarkan sintak model pembelajaran inkuiri, yaitu mulai dari mengeksplorasi fenomena, memfokuskan pertanyaan, merencanakan investigasi, melaksanakan invetigasi, menganalisis data dan hasil, sampai mengkomunikasikan. Hal tersebut sesuai dengan pendapat Sutama, dkk (2014) bahwa langkah model inkuiri menjadikan siswa lebih mampu berpikir kritis dan kinerja ilmiah.

Nilai validitas instrumen penilaian yang tinggi didapatkan karena instrumen penilaian yang dikembangkan sesuai dengan Peraturan Mentri Pendidikan dan Kebudayaan No. 66 Tahun 2013. Instrumen penilaian sikap dan keterampilan ilmiah memiliki rubrik penilaian. Menurut Priadi (2011), rubrik dapat memfokuskan perhatian guru pada aspek-aspek yang sedang dinilai, dan merupakan sarana efektif untuk menentukan kualitas pekerjaan atau performa yang dicapai oleh siswa.

Nilai validitas LKS yang tinggi didapatkan karena LKS yang dikembangkan berisi kegiatan-kegiatan dan tugas yang mengacu pada kompetensi dasar yang harus dicapai. Menurut Prastowo (2015), kegiatan dan tugas dalam LKS memiliki empat fungsi, yaitu: (1) meminimalkan peran guru, namun mengaktifkan siswa, (2) mempermudah siswa memahami materi, (3) ringkas dan kaya tugas untuk berlatih, dan (4) memudahkan pelaksanaan proses pembelajaran. LKS yang dikembangkan disesuaikan dengan langkah model inkuiri dengan memanfaatkan potensi wilayah Danau Betok. Hal ini sesuai dengan pendapat Santiningtyas, dkk (2012) menyatakan bahwa penerapan outdoor learning berbasis inkuiri menunjukkan bahwa siswa berperan aktif pada aktivitas inkuiri.

Nilai validitas handout yang tinggi didapatkan karena handout yang dikembangkan berisi materi yang mudah dipahami oleh siswa dan disesuaikan dengan kebutuhan Kurikulum 2013. Menurut Prastowo (2015) handout diberikan kepada siswa guna memudahkan mereka saat mengikuti proses pembelajaran. Handout dilengkapi dengan gambar komponen ekosistem yang diambil dari potensi wilayah Danau Betok. Hal ini sesuai dengan pendapat Widiyowati (2012) bahwa pemanfaatan potensi wilayah di dalam proses pembelajaran IPA akan lebih bermakna karena siswa dihadapkan pada peristiwa yang bersifat aktual dan alami yang dapat dipertanggungjawabkan kebenarannya. 


\section{Hasil Uji Coba Perangkat Pembelajaran}

Uji coba lapangan dilakukan untuk mengetahui pengembangan sikap ilmiah, keterampilan ilmiah, dan pengetahuan siswa, serta keterlaksanaan perangkat pembelajaran yang dikembangkan. Penilaian terhadap sikap ilmiah siswa didapatkan rata-rata kelas yaitu $83,33 \%$ dengan kriteria baik. Penilaian terhadap keterampilan ilmiah siswa didapatkan rata-rata kelas yaitu 81,79\% dengan kriteria baik. KKM (Kriteria Ketuntasan Minimal) untuk mata pelajaran IPA di SMPN 1 Tiris adalah 75. Ada beberapa siswa yang mendapatkan nilai tes tulis dibawah KKM, yaitu 6 siswa. Akan tetapi, nilai pengetahuan siswa didapatkan rata-rata kelas yaitu 79,30 sehingga memenuhi KKM. Hal ini menunjukkan bahwa perangkat pembelajaran yang dikembangkan dapat mengembangkan sikap ilmiah, keterampilan ilmiah, dan pengetahuan siswa.

Siswa belajar sains sebagai proses diperoleh melalui kegiatan ilmiah atau keterampilan ilmiah. Pembelajaran sains hendaknya diarahkan untuk mengembangkan keterampilan proses. Pemberian pengalaman secara langsung ditekankan melalui penggunaan keterampilan dan sikap ilmiah dengan tujuan untuk memahami konsepkonsep dan mampu memecahkan masalah (Zubaidah, dkk, 2013).

Penilaian keterlaksanaan perangkat pembelajaran diperoleh berdasarkan pengamatan observer selama kegiatan berlangsung. Observasi dilakukan dengan menggunkan angket lembar keterlaksanaan. Keterlaksanaan perangkat pembelajaran ditentukan oleh aktivitas guru dan siswa dalam berinkuiri. Nilai keterlaksanaan perangkat pembelajaran dapat dilihat pada Tabel 3.

Tabel 3 Keterlaksanaan Perangkat Pembelajaran

\begin{tabular}{lll}
\hline No. & Aspek yang dinilai & Rata-rata Persentase (\%) \\
\hline 1. & Pra Pembelajaran & 100,0 \\
2. & Kegiatan Awal & 100,0 \\
3. & Kegiatan Inti & 93,1 \\
4. & Kegiatan Penutup & 93,8 \\
5. & Pasca Pembelajaran & 81,3 \\
\hline & Rata-rata Keterlaksanaan (\%) & 93,7 \\
\hline & Kriteria & Sangat Baik \\
\hline
\end{tabular}

Tabel 3 menunjukkan bahwa rata-rata keterlaksanaan perangkat pembelajaran adalah 93,7\%. Hal tersebut dikarenakan siswa antusias dan serius dalam mengikuti pembelajaran yang dapat memberikan pengalaman secara langsung. Sanjaya (2010) menyatakan bahwa saat siswa dihadapakan dengan pembelajaran yang membuat siswa memperoleh pengalaman langsung, maka siswa secara otomatis juga akan memperoleh pembelajaran yang bermakna. Hal ini menunjukkan bahwa keterlaksanaan perangkat pembelajaran berada pada kriteria sangat baik. Berdasarkan kriteria tersebut dapat disimpulkan bahwa perangkat pembelajaran sangat baik digunakan dilihat dari keterlaksanaannya. 


\section{Simpulan}

\section{Kesimpulan}

Kesimpulan dari penelitian dan pengembangan ini yaitu: (1) Perangkat pembelajaran yang dikembangkan terdiri dari silabus, RPP, instrumen penilaian, bahan ajar (LKS dan handout), (2) hasil validasi perangkat pembelajaran yang dikembangkan secara keseluruhan nilai validitasnya adalah 96,2\% dengan kriteria sangat valid, (3) hasil uji coba menunjukkan bahwa nilai sikap ilmiah, keterampilan ilmiah, dan pengetahuan siswa berada pada kriteria baik, dan (4) perangkat pembelajaran dilihat dari keterlaksanaannya diperoleh nilai 93,7\% dengan kriteria sangat baik, sehingga dapat digunakan dalam pembelajaran.

\section{Saran}

Saran pemanfaatan produk pengembangan perangkat pembelajaran ini adalah dapat digunakan dengan menggunakan sumber belajar yang sejenis dengan Danau Betok dengan menyelaraskan isi perangkat pembelajaran. Saran pengembangan produk lebih lanjut yaitu, (1) penilaian pengetahuan sebaiknya dilengkapi dengan soal uraian untuk penyempurnaan penilaian, (2) proses validasi perangkat pembelajaran sebaiknya dilakukan oleh lebih banyak guru sehingga diperoleh banyak masukan untuk penyempurnaan produk, dan (3) perangkat pembelajaran yang dikembangkan sebaiknya dieksperimenkan untuk mengetahui pengaruhnya dibandingkan dengan perangkat pembelajaran yang biasanya disusun oleh guru tanpa memanfaatkan sumber belajar di sekitar siswa.

\section{Daftar Rujukan}

Ambarsari, W. (2012). Penerapan pembelajaran inkuiri terbimbing terhadap keterampilan proses sains dasar pada pelajaran biologi siswa kelas VIII SMP Negeri 7 Surakarta.

Arianto, A. (2012). Kajian Pemanfaatan Ranu Betok Sebagai Usaha Budidaya Keramba Jaring Apung dan Penangkapan Ikan di Kecamatan Tiris Kabupaten Probolinggo Jawa Timur. Skripsi (tidak diterbitkan). Fakultas perikanan dan kelautan. Universitas Brawijaya Malang.

Ibrohim, I., Nurdiana, F. R., Estiningsih, Y., \& Martiana, C. (2014). Pengembangan Perangkat Pembelajaran Ipa-Biologi Berbasis Diskoveri-Inkuiri Dengan Sumber Belajar Potensi Lingkungan Lokal Kabupaten Pasuruan. In Proceeding Biology Education Conference: Biology, Science, Enviromental, and Learning (Vol. 11, No. 1, pp. 1050-1059).

Kuhlthau, C.C., Maniotes, L.K., dan Caspari, A.K. (2007). Guided Inquiry: Learning in the 21st Century. United States of America: Library Unlimeted Inc.

Kurniawan, A. D. (2013). Metode inkuiri terbimbing dalam pembuatan media pembelajaran biologi untuk meningkatkan pemahaman konsep dan kreativitas siswa SMP. Jurnal Pendidikan IPA Indonesia, 2(1).

Mulyono, M. (2011). Strategi pembelajaran: Menuju efektifitas pembelajaran di abad global.

Pendidikan, M. (2013). Peraturan Menteri Pendidikan dan Kebudayaan Republik Indonesia. Nomor, 66, 1-3.

Pendidikan, M. (2013). Peraturan Menteri Pendidikan dan Kebudayaan Republik Indonesia. Nomor, 66, 1-3.

Pertiwi, F.A. (2012). Penerapan Metode Simulasi Tipe Role Playing untuk Menuntaskan Hasil Belajar Biologi Pokok Bahasan Ekosistem pada Siswa Kelas VIIA SMPN 9 Jember. Skripsi.

Praptiwi, L., \& Handayani, L. (2012). Efektivitas model pembelajaran eksperimen inkuiri terbimbing berbantuan my own dictionary untuk meningkatkan penguasaan konsep dan unjuk kerja siswa SMP RSBI. Unnes Science Education Journal, 1(2).

Prastowo, A. (2011). Panduan kreatif membuat bahan ajar inovatif. 
Pribadi, B. A. (2009). Model desain sistem pembelajaran. Jakarta: Dian Rakyat, 35.

Rahayu, P., Mulyani, S., \& Miswadi, S. S. (2012). Pengembangan pembelajaran IPA terpadu dengan menggunakan model pembelajaran problem base melalui lesson study. Jurnal Pendidikan IPA Indonesia, 1(1).

Riduwan, M. B. A. (2007). Skala pengukuran variabel-variabel penelitian. Alf. Bandung.

Santiningtyas, K. (2012). Pengaruh Outdoor Learning Berbasis Inkuiri Terhadap Hasil Belajar Siswa Materi Ekosistem (Doctoral dissertation, Universitas Negeri Semarang).

Sanjaya, W. (2019). Strategi pembelajaran berorientasi standar proses pendidikan.

Sutama, I. N., Arnyana, I. B. P., \& Swasta, I. B. J. (2014). Pengaruh model pembelajaran inkuiri terhadap ketrampilan berpikir kritis dan ketrampilan proses sains pada pelajaran biologi Kelas XI IPA SMA Negeri 2 Amlapura. Jurnal Pendidikan dan Pembelajaran IPA Indonesia, 4(1).

Widowati, A. (2012). Optimalisasi Potensi Lokal Sekolah dalam Pembelajaran Biologi Berbasis Kontruktivisme. Majalah Ilmiah Pembelajaran, 8(2). 